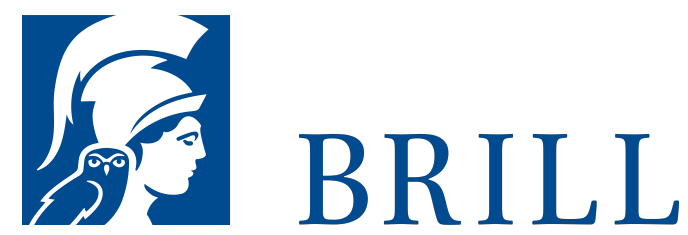

\title{
Theoriegeschichte der Photographie
}

Author: Bernd Stiegler

Dieses Buch rekonstruiert zum ersten Mal die Geschichte der Photographie von der Erfindung der Daguerreotypie um 1840 und den Reaktionen, die sie hervorgerufen hat, bis hin zur digitalen Photographie Ende des 20. Jahrhunderts als Theoriegeschichte.

Dabei geht es sowohl um die einschlägigen theoretischen Positionen (von Barthes, Derrida, Foucault, Moholy-Nagy, Emerson, Stieglitz bis hin zu Rodtschenko, Hausmann, Baudrillard, Flusser u.v.a.m.) als auch um eine Vielzahl von Texten, die erst bei genauerem Hinsehen ihren theoretischen Gehalt zeigen.

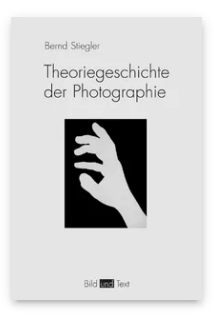

Pages: 472

Seiten, $30 \mathrm{~s} / \mathrm{w}$

Abb.

Language:

German

Subjects:

General, Media

Studies

Publisher: Brill |

Fink

Series:

Bild und Text

E-Book (PDF)

Released online:

11 Nov 2019

ISBN: 978-3-

8467-4216-7

List price

Paperback

Publication date:

20 Jan 2010

ISBN: $978-3^{-}$

7705-4216-1

List price

USD $\$ 63.00$ 
For more information see brill.com

Order information: Order online at brill.com +44330 333 0049 | customerservices@brill.com Submission information: brill.com/authors

Titles published by Brill | Fink, Brill | mentis or Brill | Schöningh: +49(o)715413279216| brill@brocom.de 